\title{
African dust influence on ambient PM levels in South- Western Europe (Spain and Portugal): A quantitative approach to support implementation of Air Quality Directives
}

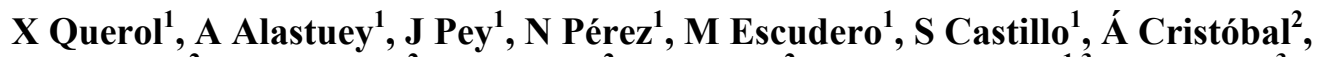 \\ M Pallarés ${ }^{2}$, A González ${ }^{2}, \mathbf{S}$ Jiménez ${ }^{2}$, N Alonso ${ }^{2}, \mathbf{S}$ Alonso-Pérez ${ }^{1,3}$, E Cuevas ${ }^{3}$ \\ and $J$ de la $\operatorname{Rosa}^{4}$ \\ ${ }^{1}$ Institute of Earth Sciences "Jaume Almera", CSIC. Barcelona, Spain \\ ${ }^{2}$ D.G. Calidad y Evaluación Ambiental, Ministerio de Medio Ambiente, Spain \\ ${ }^{3}$ Izaña Atmospheric Research Center. Agencia Estatal de Meteorología. Tenerife, \\ Spain. \\ ${ }^{4}$ Universidad de Huelva, Spain \\ E-mail: xavier.querol@ija.csic.es
}

\begin{abstract}
This manuscript proposes and validates a methodology for the quantification of the daily African PM load during dust outbreaks in southern Europe. The daily net dust load in $\mathrm{PM}_{10}$ attributable to an African episode can be obtained by subtracting the daily regional background (RB) level from the $\mathrm{PM}_{10}$ concentration value at a $\mathrm{RB}$ station. The daily $\mathrm{RB}$ level can be obtained by applying a monthly moving $30^{\text {th }}$ percentile to the $\mathrm{PM}_{10}$ time series at a $\mathrm{RB}$ station after a prior extraction of the data coincident with African dust transport. For days with influence of African dust, the dust load is given by the difference between the daily $\mathrm{PM}_{10}$ values minus the daily $\mathrm{PM}_{10} \mathrm{RB}$ levels. This method allows us to quantify the net African dust load without chemical speciation. The comparison between the estimated net load during African dust outbreaks (ADO) and the crustal load determined by chemical speciation of $\mathrm{PM}_{10}$ filters at three $\mathrm{RB}$ stations in Spain had resulted in a very good correlation $\left(\mathrm{R}^{2}=0.60-0.83\right)$, being the equivalence (correlation lines' slopes $\sim 1$ ) highly significant in the three cases.
\end{abstract}

\section{Introduction}

The determination of the levels of atmospheric particulate matter (PM) is a key parameter in the evaluation of air quality given the proven influence of this pollutant on human health [1] and climate ([2] and references therein). As regards the adverse health effects of PM, the European Commission (EC) issued the Directive 1999/30/EU on air quality. This Directive established $\mathrm{PM}_{10}$ as a parameter to be monitored, with annual $\left(40 \mu \mathrm{g} \mathrm{m}^{-3}\right)$ and daily $\left(50 \mu \mathrm{g} \mathrm{m}^{-3}\right.$, not to be exceeded more than 35 occasions per year) limit values.

In cases where the exceedances of the limit values can be attributed to natural phenomena such as the transport of natural particles from arid regions, they can be discounted after scientific validation (article 2.15 from the 1999/30/EC Directive).

In southern Europe, the ADO may have a great impact on the PM levels $[3,4,5,6,7]$. Thus, at the Spanish EMEP (Co-operative Programme for Monitoring and Evaluation of the Long-Range Transmission of Air pollutants in Europe) sites more than $70 \%$ of the exceedances of the daily $\mathrm{PM}_{10}$ 
limit value are attributable to African dust contributions [8]. However, during ADO the $\mathrm{PM}_{10}$ fraction is not entirely composed of African crustal aerosols. [4] estimated that between 20-50\% of the $\mathrm{PM}_{10}$ concentration at RB sites during $\mathrm{ADO}$ in NE Spain had a regional or local origin different from mineral dust. In addition, as discussed in [8], the formation of secondary aerosols is enhanced during $\mathrm{ADO}$ due to the interaction of local anthropogenic species with mineral dust components.

The most common approach to quantifying dust contribution is the development of chemical speciation studies. The main disadvantages of chemical speciation are the high economic cost and the length of the process.

In the light of the foregoing discussion, we propose a quantitative and simple methodology for estimating the net African dust load in $\mathrm{PM}_{10}$ during $\mathrm{ADO}$. This methodology has been validated by chemical speciation data for three RB sites in Spain.

\section{Methods}

\subsection{Measurements and interpretation}

The variability of $\mathrm{PM}_{10}$ levels from thirteen $\mathrm{RB}$ stations was interpreted. The air quality monitoring stations selected are representative of the different climatic areas of the Iberian Peninsula (table 1 and figure 1). $\mathrm{PM}_{10}$ measurements at EMEP stations were performed by means of the gravimetric method making use of MCV-PM1025 samplers $\left(30 \mathrm{~m}^{3} \mathrm{~h}^{-1}\right)$. At Valderejo and Izki, $\mathrm{PM}_{10}$ measurements have been carried out using $\beta$-attenuation instrumentation and, at Monagrega, $\mathrm{PM}_{10}$ levels have been obtained with TEOM instrumentation. $\mathrm{PM}_{10}$ real time levels were corrected through the application of the correction factors obtained by comparison with the gravimetric measurements.

Table 1. Spanish RB stations providing $\mathrm{PM}_{10}$ data.

\begin{tabular}{|c|c|c|c|c|c|}
\hline Station & $\begin{array}{l}\text { Air quality monitoring } \\
\text { network }\end{array}$ & Location & $\begin{array}{l}\text { Altitude } \\
\text { (m.a.s.1.) }\end{array}$ & $\mathrm{PM}_{10}$ monitoring & $\begin{array}{c}\text { Sampling period } \\
\left(\mathrm{PM}_{10} \text { Chemical Speciation) }\right.\end{array}$ \\
\hline O Saviñao & EMEP & $\begin{array}{l}42^{\circ} 38^{\prime} \mathrm{N} \\
07^{\circ} 42^{\prime} \mathrm{W}\end{array}$ & 506 & Gravimetric & $2001-2003$ \\
\hline Niembro-Llanes & EMEP & $\begin{array}{l}43^{\circ} 26^{\prime} \mathrm{N} \\
04^{\circ} 51^{\prime} \mathrm{W}\end{array}$ & 134 & Gravimetric & 2001-2003 \\
\hline Valderejo & $\begin{array}{l}\text { Government of the Basque } \\
\text { Country }\end{array}$ & $\begin{array}{l}42^{\circ} 53^{\prime} \mathrm{N} \\
03^{\circ} 14^{\prime} \mathrm{W}\end{array}$ & 911 & $\beta$-Attenuation & Since 2000 \\
\hline Izki & $\begin{array}{l}\text { Government of the Basque } \\
\text { Country }\end{array}$ & $\begin{array}{l}42^{\circ} 39^{\prime} \mathrm{N} \\
02^{\circ} 30^{\prime} \mathrm{W}\end{array}$ & 835 & $\beta$-Attenuation & Since 2001 \\
\hline Cabo de Creus & EMEP & $\begin{array}{l}42^{\circ} 19^{\prime} \mathrm{N} \\
03^{\circ} 19^{\prime} \mathrm{E}\end{array}$ & 23 & Gravimetric & $2001-2003$ \\
\hline Els Torms & EMEP & $\begin{array}{l}41^{\circ} 24^{\prime} \mathrm{N} \\
00^{\circ} 43^{\prime} \mathrm{E}\end{array}$ & 470 & Gravimetric & $2001-2003$ \\
\hline Monagrega & ENDESA & $\begin{array}{l}40^{\circ} 59^{\prime} \mathrm{N} \\
00^{\circ} 12^{\prime} \mathrm{W}\end{array}$ & 600 & TEOM & $\begin{array}{c}\text { Since } 1996 \\
(24 / 03 / 1999-06 / 07 / 2000)\end{array}$ \\
\hline Risco Llano & EMEP & $\begin{array}{l}39^{\circ} 31^{\prime} \mathrm{N} \\
04^{\circ} 21^{\prime} \mathrm{W}\end{array}$ & 1241 & Gravimetric & 2001-2003 \\
\hline Campisábalos & EMEP & $\begin{array}{l}41^{\circ} 17^{\prime} \mathrm{N} \\
03^{\circ} 09^{\prime} \mathrm{W}\end{array}$ & 1360 & Gravimetric & $2001-2003$ \\
\hline Peñausende & EMEP & $\begin{array}{l}41^{\circ} 17^{\prime} \mathrm{N} \\
05^{\circ} 52^{\prime} \mathrm{W}\end{array}$ & 985 & Gravimetric & $2001-2003$ \\
\hline Zarra & EMEP & $\begin{array}{l}39^{\circ} 05^{\prime} \mathrm{N} \\
01^{\circ} 06^{\prime} \mathrm{W}\end{array}$ & 885 & Gravimetric & $2001-2003$ \\
\hline Barcarrota & EMEP & $\begin{array}{l}38^{\circ} 29^{\prime} \mathrm{N} \\
06^{\circ} 55^{\prime} \mathrm{W}\end{array}$ & 393 & Gravimetric & $2001-2003$ \\
\hline Víznar & EMEP & $\begin{array}{l}37^{\circ} 14^{\prime} \mathrm{N} \\
03^{\circ} 28^{\prime} \mathrm{W}\end{array}$ & 1265 & Gravimetric & $2001-2003$ \\
\hline Montseny & $\begin{array}{l}\text { CSIC-Generalitat de } \\
\text { Catalunya Goverment }\end{array}$ & $\begin{array}{l}41^{\circ} 46^{\prime} \mathrm{N} \\
02^{\circ} 21^{\prime} \mathrm{E}\end{array}$ & 720 & $\begin{array}{c}\text { Laser } \\
\text { Spectrometer }\end{array}$ & $\begin{array}{l}\text { Since } 2002 \\
\text { (Since 2002) }\end{array}$ \\
\hline $\begin{array}{l}\text { Castillo de } \\
\text { Bellver }\end{array}$ & Illes Balears Goverment & $\begin{array}{l}39^{\circ} 34^{\prime} \mathrm{N} \\
02^{\circ} 37^{\prime} \mathrm{E}\end{array}$ & 117 & $\beta$-Attenuation & $\begin{array}{c}2004-2005 \\
(08 / 01 / 2004-29 / 97 / 2005)\end{array}$ \\
\hline
\end{tabular}




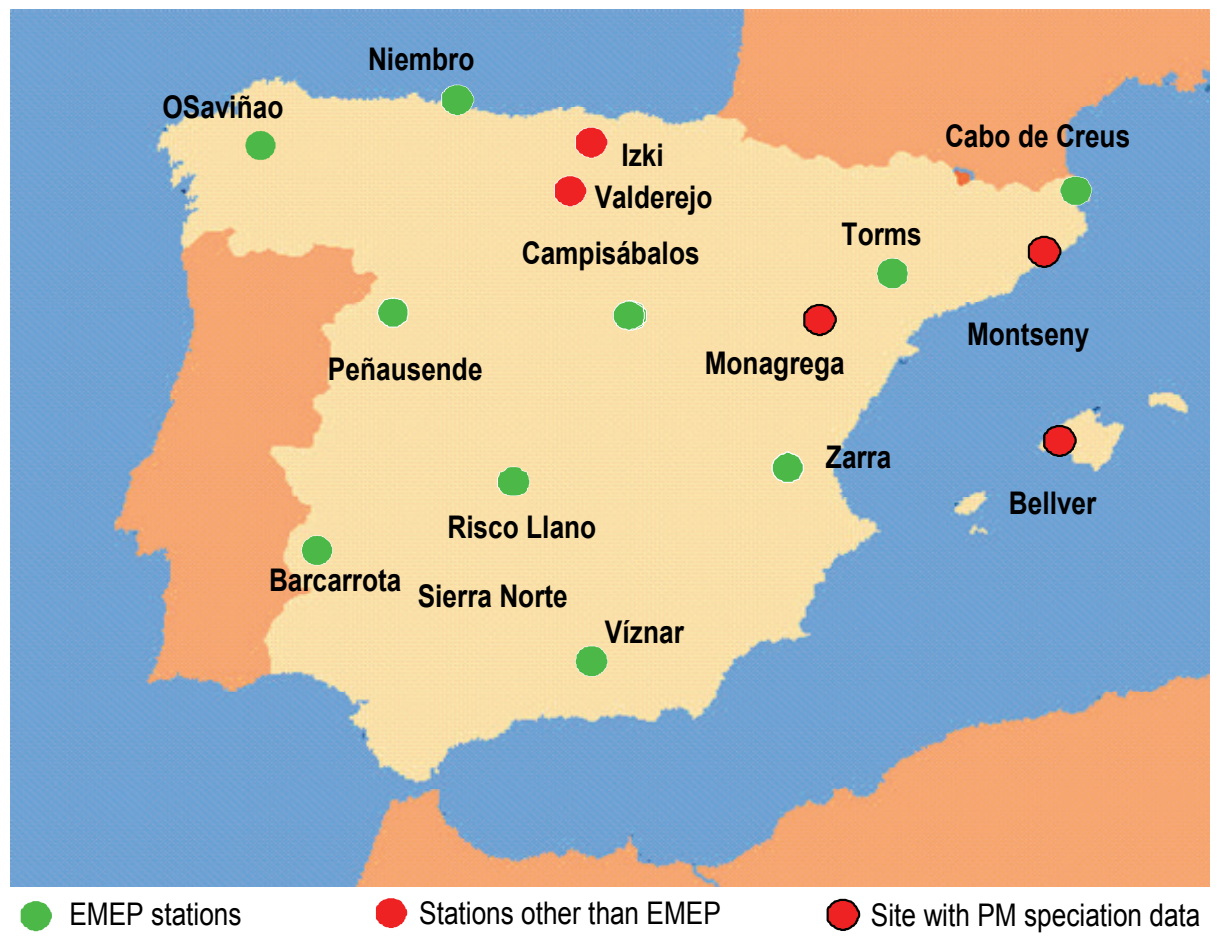

Figure 1. Spanish RB stations providing $\mathrm{PM}_{10}$ data and/or chemical speciation data.

The interpretation of the origin of the air masses reaching each of these monitoring sites was performed by calculating back-trajectories with the HYSPLIT4 model [9] accomplished with other tools such as meteorological maps, numerical models, and satellite images (see details in [5]).

\section{2. $\mathrm{PM}_{10}$ speciation}

In order to validate the methodology proposed here, data on chemical speciation of $\mathrm{PM}_{10}$ from three RB sites located in the Iberian Peninsula and the Balearic Islands were used (Monagrega, Montseny and Castillo de Bellver, table 1 and figure 1). 24-hour samples of $\mathrm{PM}_{10}$ were collected in quartz fibre filters twice per week. The instruments for the gravimetric samplings were high volume samplers working at $30 \mathrm{~m}^{3} \mathrm{~h}^{-1}$. At Monagrega and at Montseny, DIGITEL inlets were used whereas MCVPM1025 instrumentation was used at Castillo de Bellver.

Once $\mathrm{PM}_{10}$ levels were gravimetrically determined, the filters were analyzed by different techniques to quantify the concentrations of approximately $60 \mathrm{PM}$ components [10]. The concentrations of the major crustal components $\left(\mathrm{SiO}_{2}, \mathrm{Al}_{2} \mathrm{O}_{3}, \mathrm{CO}_{3}{ }^{2-}, \mathrm{Ca}, \mathrm{Mg}, \mathrm{Fe}\right.$ and $\left.\mathrm{K}\right)$ accounted for $>99 \%$ of the mineral dust load.

\section{Results}

\subsection{Identification of African episodes affecting PM levels}

The identification of the origin of the air masses reaching the regional monitoring sites and the interpretation of the origin of PM events was carried out following the above methodology (see details in [5]).

The persistence of some African dust episodes has been taken into account. It should be noted that $\mathrm{PM}_{10}$ levels may be high at RB stations one day before and/or two days after the period with proven 
influence of African dust. This could arise when the African air masses transported towards the Iberian Peninsula are not followed by episodes of intense advection. According to other studies, African dust transported towards southern Europe reaches a minimum altitude of 1500 m.a.s.l. [11]. The deposition of particles between 1 and 10 microns has an average speed of $0.6 \mathrm{~cm} \mathrm{~s}^{-1}$ [12]. Thus, levels of PM could remain high at a given site two days after the episode had ended and, therefore, the African period could also include these dates.

\subsection{Calculation of the RB levels}

During Atlantic advection episodes in Spain, $\mathrm{PM}_{10}$ levels are at their lowest owing to the reduced external contributions. At an specific RB site, the mean moving average of Atlantic advection can be considered as similar to the RB $\mathrm{PM}_{10}$ levels. This was performed at the $13 \mathrm{RB}$ sites (table 1 and figure 1) for the period 2001-2003. The execution of this procedure requires daily interpretation of the air masses origin, and therefore, is not a straightforward method to be applied by the air monitoring networks.

In order to simplify the calculation of the $\mathrm{RB} \mathrm{PM}_{10}$ levels, we propose the application of a monthly moving percentile to the $\mathrm{PM}_{10}$ series, after excluding the data corresponding to the days with ADO. This method is easier to apply given that only the days with influence of African dust transport need to be identified. In order to select the most adequate percentile, we performed a sensitivity test using different percentile thresholds $\left(5,10,30,40\right.$ and $\left.50^{\text {th }}\right)$ at the $13 \mathrm{RB}$ stations. As shown in figure 2, the application of the 10 and $30^{\text {th }}$ percentiles ( $y=1.44 \mathrm{x}$ and $\mathrm{y}=1.07 \mathrm{x}$, respectively) underestimates the $\mathrm{RB}$ levels when compared with those calculated after considering only the days with Atlantic advection. By contrast, the use of the 40 and $50^{\text {th }}$ percentiles yielded an overestimation of the RB levels ( $y=0.96 x$ and $y=0.86 x$, respectively). Thus, the $30^{\text {th }}$ and $40^{\text {th }}$ percentiles proved to be the most suitable. In order to reduce the underestimation of the African dust load we propose the adoption of the $30^{\text {th }}$ percentile.

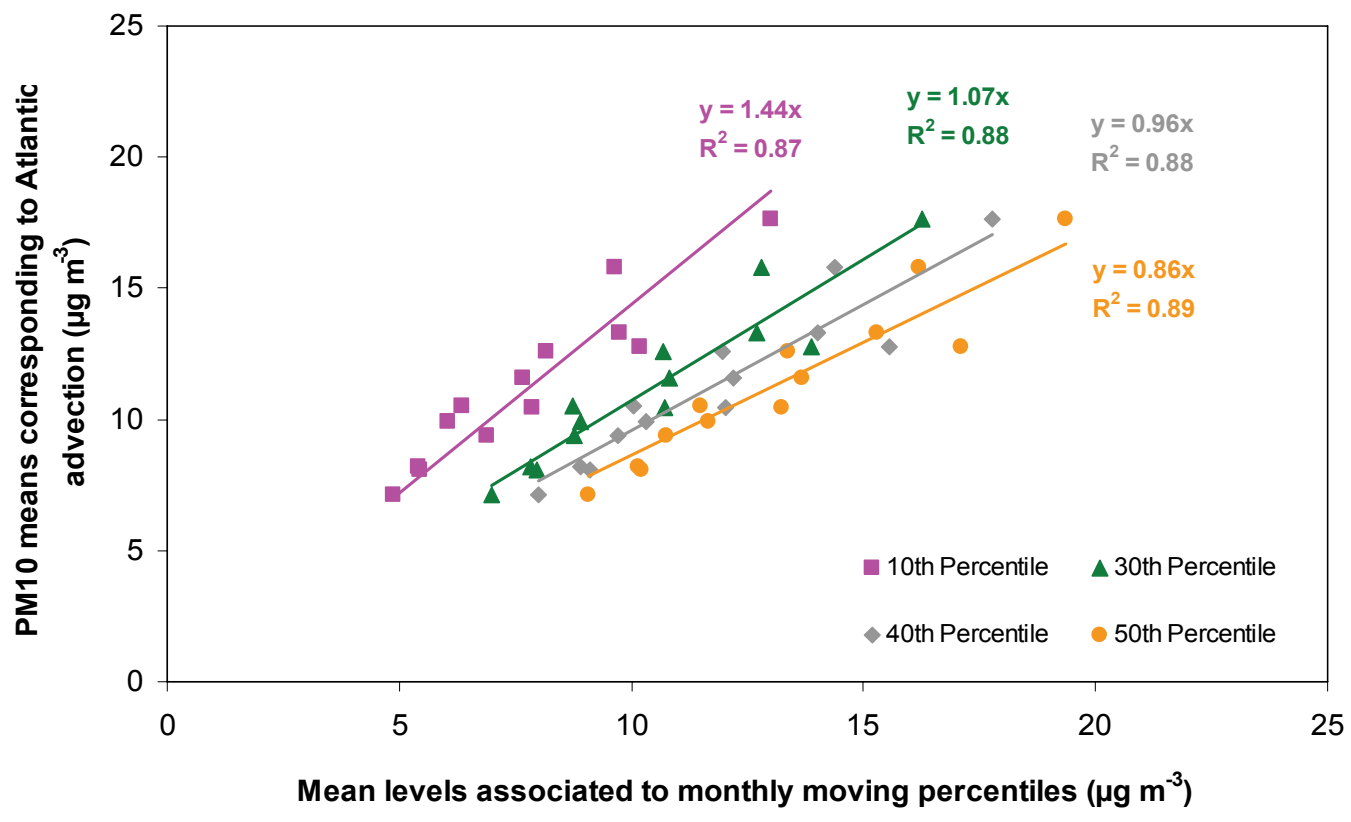

Figure 2. Correlation between the $\mathrm{PM}_{10}$ averages calculated only for the days with Atlantic advection (ATL) and the means of the time series obtained after applying different monthly moving percentiles $\left(5^{\text {th }}, 10^{\text {th }}, 30^{\text {th }}, 40^{\text {th }}\right.$ and $\left.50^{\text {th }}\right)$ to the $\mathrm{PM}_{10}$ data from 13 RB stations of the Iberian Peninsula for the period 2001-2003. 


\subsection{Calculation of the net African dust load and validation}

The daily net African dust load was calculated by subtracting the daily RB level (obtained with the $30^{\text {th }}$ percentile) from the daily $\mathrm{PM}_{10}$ value registered during an ADO.

In order to validate this method, we compared the mineral matter (sum of $\mathrm{SiO}_{2}, \mathrm{Al}_{2} \mathrm{O}_{3}, \mathrm{CO}_{3}{ }^{2-}, \mathrm{Ca}$, $\mathrm{Mg}, \mathrm{Fe}$ and $\mathrm{K}$ ) load for days with $\mathrm{ADO}$ from three RB monitoring stations (Monagrega, Montseny and Castillo de Bellver, Figure 1) with the net dust contribution calculated by using the proposed method. As shown in figure 3, the crustal load determined by chemical speciation strongly correlated $\left(0.60<\mathrm{R}^{2}<0.69\right)$ with the net African dust load calculated. Therefore, the net African dust load calculated is mainly composed of mineral matter, which corroborates the major natural origin of the $\mathrm{PM}_{10}$ fraction, although sulphation and nitration of dust is evidenced in specific cases.

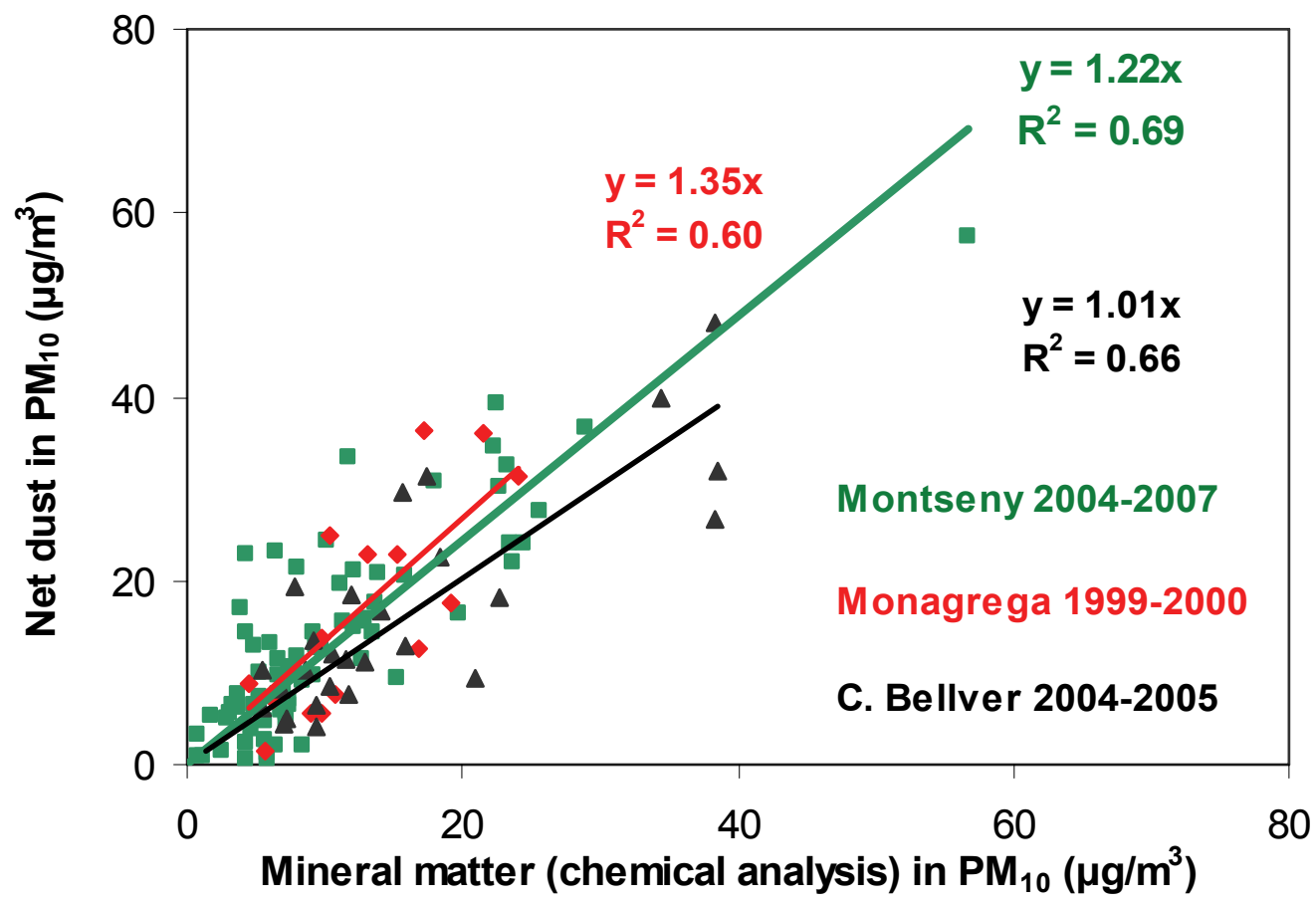

Figure 3. Correlation between the net African dust load obtained with the proposed methodology and the crustal load in $\mathrm{PM}_{10}$ determined by chemical speciation at Monagrega, Montseny and Castillo de Bellver.

\subsection{Application of this method during exceedences of the daily limit value of $\mathrm{PM}_{10}$}

When the $\mathrm{PM}_{10}$ daily limit value is exceeded at urban or industrial stations during an $\mathrm{ADO}$, the net African dust load can be used to evaluate the impact of the natural contribution to that exceedance. For example, at two stations, urban background and kerbside, 60 and $100 \mu \mathrm{gPM}_{10} \mathrm{~m}^{-3}$ are measured, respectively, on a given day during an ADO. Simultaneously, at the closest RB site, a daily value of 41 $\mu \mathrm{gPM}_{10} \mathrm{~m}^{-3}$ is measured, and the monthly moving $30^{\text {th }}$ percentile value is $10 \mu \mathrm{g} \mathrm{m}^{-3}$ for this day. Therefore, the net African dust load in this region, for this day, is $31 \mu \mathrm{gPM}_{10} \mathrm{~m}^{-3}$. In this case, the exceedance at the urban background site can be attributed to the dust contribution (60-31 $=29 \mu \mathrm{gPM}_{10}$ $\mathrm{m}^{-3}$ as anthropogenic load), whereas the at the kerbside station must be ascribed to anthropogenic contributions $\left(100-31=69 \mu \mathrm{gPM}_{10} \mathrm{~m}^{-3}\right)$.

In some cases, negative values could be obtained when subtracting the net African dust load. In these situations, the net African dust load should be calculated at another RB station in the vicinity of the urban or industrial station at approximately the same altitude. 


\section{Acknowledgements}

This study was supported by the S.G.D. Environmental Quality and Industrial Environment from the Spanish Ministry of the Environment, but also by research projects from the Ministry of Science and Innovation (CGL2005-03428- C04-03/CLI, CGL2007-62505/CLI, GRACCIE- CSD2007-00067), the European Union (6th framework CIRCE IP, 036961, EUSAAR RII3-CT-2006-026140) and the Ministry of the Environment (CALIOPE, 441/2006/3-12.1). The authors would like to express their gratitude to the Atmospheric Modelling \& Weather Forecasting Group in the University of Athens, the Earth Sciences Department of the Barcelona Supercomputing Center, the NASA/Goddard Space Flight Center, NOAA Air Resources Laboratory (ARL), the Naval Research Laboratory and the SeaWiFS project (NASA) for the provision of the SKIRON, DREAM, TOMS, NAAPs aerosol maps and the satellite imagery, respectively. The authors are also indebted to the Spanish Ministry of the Environment for providing data from EMEP air quality network, the Autonomous Government of the Basque Country for supplying data from Valderejo and Izki stations and ENDESA-Teruel for providing data from Monagrega station. Finally, the authors gratefully acknowledge the NOAA Air Resources Laboratory (ARL) for the provision of HYSPLIT model.

\section{References}

[1] Pope C.A. and Dockery D.W. 2006 Health effects of fine particulate air pollution: lines that connect, A Journal of the Air \& Waste Man. Ass., 56, 709-742.

[2] IPCC, 2007. Climate Change 2007: The Physical Science Basis. Contribution of Working Group I to the Fourth Assessment Report of the IPCC (ISBN 9780521 88009-1 Hardback; 9780521 70596-7 Paperback).

[3] Querol X., Alastuey A., Puicercus J.A., Mantilla E., Miró J.V., López-Soler A., Plana F. and Artíñano B. 1998 Seasonal Evolution of Suspended Particles Around a Large Coal-Fired Power Station: Particle Levels and Sources, Atm. Env., 32, 1963-1978.

[4] Rodríguez S., Querol X., Alastuey A. and Plana F. 2002 Sources and processes affecting levels and composition of atmospheric aerosol in the Western Mediterranean, Journal of Geophysical Research, 107 (D24), 4777.

[5] Escudero M., Castillo S., Querol X., Avila A., Alarcón M., Viana M.M., Alastuey A., Cuevas E. and Rodríguez S. 2005 Wet and dry African dust episodes over Eastern Spain, Journal of geophysical research, 110 (D18S08), 10.1029.

[6] Gerasopoulos E., Kouvarakis G., Babasakalis P., Vrekoussis M., Putaud J.P. and Mihalopoulos N. (2006). Origin and variability of particulate matter (PM10) mass concentrations over the Eastern Mediterranean, Atm. Env., 40, 4679-4690.

[7] Gobbi G.P., Barnaba F. and Ammannato L. 2007 Estimating the impact of Saharan dust on the year 2001 PM10 record of Rome, Italy, Atm. Env., 41, 261-275.

[8] Escudero M., Querol X., Avila A. and Cuevas E. 2007 Origin of the exceedances of the European daily PM limit value in regional background areas of Spain, Atm. Env., 41, 730744.

[9] Alastuey A., Querol X., Castillo S., Escudero M., Avila A., Cuevas E., Torres C., Romero P.M., Expósito F., Garcia O., Diaz J.P., Dingenen R.V. and Putaud J.P. 2005 Characterisation of TSP and $\mathrm{PM}_{2.5}$ at Izaña and Sta. Cruz de Tenerife (Canary Islands, Spain) during a Saharan dust episode (July 2002), Atm. Env., 39, 4715-4728.

[10] Draxler R.R. and G.D. Rolph 2003 HYSPLIT (HYbrid Single-Particle Lagrangian Integrated Trajectory). Website: http://www.arl.noaa.gov/ready/hysplit4.html, NOAA Air Resources Laboratory, Silver Spring, MD.

[11] Querol X., Alastuey A., Rodríguez S., Plana F., Ruiz C.R., Cots N., Massagué G. and Puig O. $2001 \mathrm{PM}_{10}$ and $\mathrm{PM}_{2.5}$ source apportionment in the Barcelona Metropolitan Area, Catalonia, Spain, Atm. Env., 35, 6407-6419. 
[12] Pérez C., Sicard M., Jorba O., Comeron A. and Baldasano J.M. 2004 Summertime recirculations of air pollutants over the north-eastern Iberian coast observed from systematic EARLINET lidar measurements in Barcelona, Atm. Env., 38, 3983-4000.

[13] Zender C.S., Bian H.S. and Newman D. 2003 Mineral Dust Entrainment and Deposition (DEAD) model: Description and 1990s dust climatology, Journal of geophysical research, 108 (D14), Art. No. 4416. 